\title{
Combined alkali and hydrothermal pretreatments for oat straw valorization within a biorefinery concept
}

\author{
Aloia Romaní ${ }^{\mathrm{a}, \mathrm{b}}$, Pablo D. Tomaz ${ }^{\mathrm{b}}$, Gil Garrote ${ }^{\mathrm{b}, \mathrm{c}}$, José A. Teixeira ${ }^{\mathrm{a}}$, Lucília Domingues ${ }^{\mathrm{a}, *}$ \\ ${ }^{a}$ CEB-Centre of Biological Engineering, University of Minho, Campus Gualtar, 4710-057 Braga, Portugal \\ ${ }^{\mathrm{b}}$ Department of Chemical Engineering, Faculty of Science, University of Vigo (Campus Ourense), As Lagoas, 32004 Ourense, Spain \\ ${ }^{c}$ CITI-Tecnopole, San Ciprián das Viñas, 32901 Ourense, Spain
}

\section{H I G H L I G H T S}

- Oat straw was revalorized following a biorefinery approach.

- Two configurations of process were developed: lime combined or/not with autohydrolysis.

- $68 \%$ of hemicellulose was recovered as oligosaccharides using autohydrolysis.

- Ethanol concentration higher than $4 \%$ $(\mathrm{w} / \mathrm{w})$ was achieved in two different strategies.

\section{A R T I C L E I N F O}

\section{Article history:}

Received 8 July 2016

Received in revised form 18 August 2016

Accepted 20 August 2016

Available online 24 August 2016

\section{Keywords:}

Oat straw

Lime pretreatment

Autohydrolysis

Biorefinery

Bioethanol
G R A P H I C A L A B S T R A C T

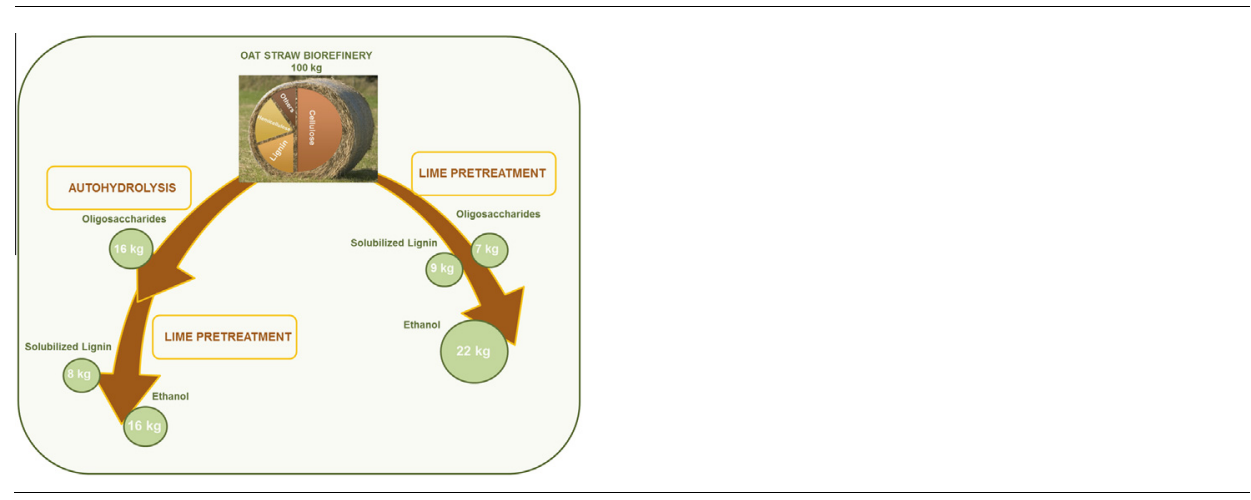


Processing of lignocellulosic biomass for bioethanol production requires at least one first stage pretreatment to alter its complex structure and improve the enzymatic saccharification of polysaccharides into fermentable sugars. Lignocellulosic pretreatment is considered the most expensive step involved in bioethanol production (Yang and Wyman, 2008). Therefore, the development of a cost-efficient pretreatment is one of the main challenges for lignocellulosic bioethanol commercialization. Only a few pretreatments have been identified as leading pretreatments (Wyman et al., 2011) and/or cost-effective processes, including steam explosion, liquid hot water or autohydrolysis, dilute acid and alkali pretreatments (Zu et al., 2014; Singh et al., 2015). A comparative study based on techno-economic analysis of several pretreatments for ethanol production showed that the minimum ethanol selling price obtained by hydrothermal and alkali lime processes was considerably reduced when two fractions (hemicellulose and cellulose) were employed in ethanol fermentation (Tao et al., 2011). Alkali treatment is recognized as an efficient delignification process to remove lignin and enhance enzymatic susceptibility of cellulose (Rabelo et al., 2013). Lime $\left(\mathrm{Ca}(\mathrm{OH})_{2}\right)$ is used as alternative alkali for biomass processing at low temperature and pressure and has additional benefits compared to $\mathrm{NaOH}$ or $\mathrm{KOH}$ (low cost reagent, less safety requirements and easily recovered) (Mosier et al., 2005; Wang and Cheng, 2011). In addition, lower degradation of sugars (or inhibitors formation) during alkali process is produced compared to acid pretreatment (Jasaimut et al., 2013). Alternatively, lime processing can also be combined to previous pretreatment in order to improve the selective fractionation of lignocellulose biomass (into main components: cellulose, hemicellulose and lignin), achieving a more efficient process within a biorefinery scheme (Romaní et al., 2011; Ruiz et al., 2011). Hydrothermal treatment or liquid hot water is a recognized environmentally-friendly pretreatment used as first step of a biorefinery for extraction of hemicellulosic fraction into oligosaccharides (Garrote et al., 1999; Yañez et al., 2009) and it has been successfully combined with other treatment for improvement of ethanol production (Romaní et al., 2011; Akhtar et al., 2016).

Agricultural residues (as straw from crops) are considered as one of the most important potential sources of renewable lignocellulosic biomass for bioethanol production (Kim and Dale, 2004). In addition, the use of agricultural wastes is a less controversial solution than the use of whole energy crop (usually employed as food crops) (Gómez-Tovar et al., 2012). Straw from crops such as barley, oat, rice, sorghum and wheat are distinguishable by its high carbohydrate content (54-70\%) that implies a potential ethanol production ranging from 0.26 to $0.31 \mathrm{~L} / \mathrm{kg}$ of dry biomass (Kim and Dale, 2004). The fermentation of all sugars present in lignocellulose biomass (hemicellulosic sugars such as xylose and glucose from saccharification of cellulose) is another of identified challenge for ethanol production since the main strain used for ethanol production (Saccharomyces cerevisiae) is not able to consume xylose, naturally. Recent advances in this field reveal that the suitable selection of host strain for metabolic engineering xylose pathway is of the utmost importance since the strain background could improve the lignocellulose-to-bioethanol processes (Jin et al., 2013; Wimalasena et al., 2014). Industrial environments have been identified as a promising source of natural robust strains (Pereira et al., 2014) suitable for metabolic engineering in order to develop more efficient strains for lignocellulosic processes (Romaní et al., 2015; Cunha et al., 2015).

Oat is one of the major crops produced annually (Kim and Dale, 2004) with an annual production of $21 \mathrm{M}$ tonnes being Russia the highest producer (FAO). Oat straw has not been as extensively studied as wheat straw, corn cob and sugarcane. Scientific researches about valorization of oat straw residues include the manufacturing of functional food (as prebiotics) (Berger et al.,
2014) and its bioconversion to biofuel energy as bioethanol, biogas and methane (Dereire et al., 2010; Sapci, 2013; Gómez-Tovar et al., 2012). On the other hand, a suitable process configuration for an integral use of oat straw fractions could lead to multi-products in a biorefinery scheme which would fulfill the requirements for a sustainable growth.

The objective of this work was the development of oat strawbased biorefinery by cost-effective pretreatment technologies (lime treatment and autohydrolysis). Two possible configurations were followed: lime pretreatment and sequential stages of autohydrolysis and lime treatment. Overall mass balance of the two configurations was performed in order to compare recovery of main components (cellulose, hemicellulose and lignin) and evaluate the efficiency of pretreatments on oat straw fractionation. In addition, susceptible pretreated oat straw samples were subjected to simultaneous saccharification and fermentation for bioethanol production.

\section{Materials and methods}

\subsection{Raw material and analysis composition}

Oat (Avena sativa $L$ ) straw, raw material used in this work, was kindly provided by a local company in the southern of Spain. Oat straw was milled to pass an $8 \mathrm{~mm}$ screen, homogenized in a single lot and stored in a dry and dark place until its use. Oat straw was analyzed for aqueous and ethanol extractives, ashes, carbohydrate and lignin following NREL protocols (NREL/TP-510-42618-42622-42618). Oat straw samples were Soxhlet extracted with distilled water $(1 \mathrm{~g}$ of oat straw per $50 \mathrm{~g}$ of distilled water) for $8 \mathrm{~h}$ at $100{ }^{\circ} \mathrm{C}$ in order to determinate the aqueous extractives. After that, $1 \mathrm{~g}$ of oat straw (without aqueous extractives) was Soxhlet extracted with $50 \mathrm{~g}$ of $80 \%$ of ethanol for $8 \mathrm{~h}$ at $80^{\circ} \mathrm{C}$ to quantify the ethanol extractives. Oat straw was subjected to quantitative acid hydrolysis with $72 \%$ sulphuric acid for polysaccharides determination (measured as monosaccharides by HPLC using an index detector, Biorad Aminex HPX-87H column, eluted with $0.006 \mathrm{~N} \mathrm{H}_{2} \mathrm{SO}_{4}$, flow rate of $0.6 \mathrm{~mL} / \mathrm{min}$, oven temperature of $50^{\circ} \mathrm{C}$ ). Klason lignin content was gravimetrically determined.

\subsection{Oat straw processing}

\subsubsection{Lime pretreatment}

Samples of oat straw ( $10 \mathrm{~g})$ were mixed with $100 \mathrm{~g}$ of water, placed in a $250 \mathrm{~mL}$ flask and subjected to lime pretreatment under conditions listed in Table 1 (run 1-12) in which temperature, time and $\mathrm{Ca}(\mathrm{OH})_{2}$ loading were evaluated. Experiments carried out at 121 and $134^{\circ} \mathrm{C}$ were autoclaved (miniclave of $12 \mathrm{~L}$ ) and for experiments at $90^{\circ} \mathrm{C}$, it was employed a thermostatic oil bath. After treatment, pretreated samples were washed with abundant water until $\mathrm{pH}=7$, weighted for solid yield (SY) determination and analyzed for glucan, xylan and Klason lignin content (as it was described in Section 2.1). For an easier interpretation of results, the recovery of glucan, xylan and Klason lignin were calculated by the followed equation:

$$
R_{G n \text { or } X n \text { or } K L}=S Y \cdot \frac{G n \text { or } X n \text { or } K L}{G n_{R M} \text { or } X n_{R M} \text { or } K L_{R M}}
$$

where, subscripts $\mathrm{Gn}, \mathrm{Xn}$ and $\mathrm{KL}$ are referred to recovery (R) of glucan, xylan and Klason lignin, respectively and RM to raw material (oat straw). SY is solid yield (g of lime pretreated oat straw/100 g of oat straw).

Percentage of delignification was also calculated and employed for the discussion of results using the following equation: 
Table 1

Operational conditions of lime pretreatment and chemical composition of pretreated oat straw (expressed as $\mathrm{g}$ of component/100 g of lime pretreated oat straw).

\begin{tabular}{|c|c|c|c|c|c|c|c|c|}
\hline \multicolumn{4}{|c|}{ Operational conditions } & \multirow{2}{*}{$\begin{array}{l}\text { Solid yield } \\
(\mathrm{g} / 100 \mathrm{~g})\end{array}$} & \multicolumn{3}{|l|}{ Solid composition } & \multirow{2}{*}{$\begin{array}{l}\text { Glucan/klason } \\
\text { lignin }(\mathrm{g} / \mathrm{g})\end{array}$} \\
\hline Run & Time (min) & Temperature $\left({ }^{\circ} \mathrm{C}\right)$ & Lime loading (g/g) & & Glucan (g/100 g) & Xylan (g/100 g) & Klason lignin (g/100 g) & \\
\hline 1 & 60 & 121 & 0.4 & 63.7 & 43.4 & 16.4 & 17.0 & 2.55 \\
\hline 2 & 60 & 121 & 0.2 & 62.2 & 49.1 & 18.8 & 19.8 & 2.28 \\
\hline 3 & 60 & 121 & 0.6 & 55.5 & 46.0 & 18.0 & 18.9 & 2.44 \\
\hline 4 & 60 & 121 & 0.1 & 69.3 & 44.6 & 18.2 & 18.8 & 2.38 \\
\hline 5 & 30 & 134 & 0.1 & 69.1 & 48.9 & 18.6 & 18.0 & 2.71 \\
\hline 6 & 30 & 134 & 0.4 & 62.6 & 51.8 & 20.2 & 17.5 & 2.96 \\
\hline 7 & 60 & 134 & 0.1 & 58.1 & 51.0 & 19.9 & 18.3 & 2.79 \\
\hline 8 & 60 & 134 & 0.4 & 54.8 & 52.6 & 20.6 & 17.1 & 3.08 \\
\hline 9 & 240 & 90 & 0.4 & 66.2 & 45.4 & 19.6 & 16.4 & 2.77 \\
\hline 10 & 60 & 90 & 0.4 & 70.5 & 42.7 & 20.1 & 16.8 & 2.55 \\
\hline 11 & 60 & 90 & 0.1 & 76.2 & 41.4 & 19.9 & 17.1 & 2.42 \\
\hline 12 & 240 & 90 & 0.1 & 64.7 & 45.5 & 19.5 & 16.3 & 2.79 \\
\hline
\end{tabular}

$\%$ Delignification $=\frac{K L_{R M}-K L \cdot \frac{S Y}{100}}{K L_{R M}} \cdot 100$

\subsubsection{Autohydrolysis pretreatment}

Alternatively, a sequential configuration of autohydrolysis followed by lime pretreatment was carried out in order to remove hemicellulose fraction and evaluate the effect of this previous treatment on lime process. Water was mixed with oat straw at liquid to solid ratio of $15 \mathrm{~g} / \mathrm{g}$ in a stirred stainless reactor (Parr Instruments Company, Moline, Illinois, USA) at maximal temperature $\left(\mathrm{T}_{\mathrm{MAX}}\right)$ of $205-220^{\circ} \mathrm{C}$ following the standard temperature profile reported by Romaní et al. (2010). The harshness of autohydrolysis treatments can be expressed in terms of severity $\left(\mathrm{S}_{0}\right)$ (Lavoie et al., 2010) and calculated using the expression:

$$
\begin{aligned}
& \mathrm{S}_{0}=\log R_{0}=\log \left(R_{0_{\text {HeATING }}}+R_{0_{\text {COOLING }}}\right) \\
& =\log \left[\int_{0}^{\mathrm{tMAX}} \exp \left(\frac{\mathrm{T}(\mathrm{t})-\mathrm{T}_{\mathrm{REF}}}{\omega}\right) \cdot \mathrm{dt}\right] \\
& +\left[\int_{\mathrm{tMAX}}^{\mathrm{tF}} \exp \left(\frac{\mathrm{T}^{\prime}(\mathrm{t})-\mathrm{T}_{\mathrm{REF}}}{\omega}\right) \cdot \mathrm{dt}\right]
\end{aligned}
$$

According to this expression, $\mathrm{R}_{0}$ is the severity factor, $\mathrm{t}_{\mathrm{MAX}}$ (min) is the time needed to achieve the target temperature $\mathrm{T}_{\mathrm{MAX}}\left({ }^{\circ} \mathrm{C}\right), \mathrm{t}_{\mathrm{F}}$ (min) is the time needed for the whole heating-cooling period, and $\mathrm{T}(\mathrm{t})$ and $\mathrm{T}^{\prime}(\mathrm{t})$ represent the temperature profiles in the heating and cooling stages, respectively. Calculations were made using the values usually reported for $\omega$ and $\mathrm{T}_{\mathrm{REF}}\left(14.75^{\circ} \mathrm{C}\right.$ and $100{ }^{\circ} \mathrm{C}$, respectively). $\mathrm{R}_{0}$ heating and cooling are the severity factor for the temperature profile of heating and cooling defined previously by Romaní et al. (2010).

The medium in the reactor was cooled when the desired temperature was achieved. Solid was separated from liquor by filtration and washed for solid yield determination and assayed for chemical composition (cellulose or glucan, xylan and Klason lignin). Liquor containing mainly hemicellulose-derived compounds was directly analyzed for glucose, xylose, arabinose, acetic acid, furfural and hydroxymethylfurfural (HMF) by HPLC. Other aliquot of liquor was hydrolyzed by $4 \% \mathrm{H}_{2} \mathrm{SO}_{4}\left(121^{\circ} \mathrm{C}, 20 \mathrm{~min}\right)$ for oligosaccharides determination and analyzed by HPLC.

\subsection{Enzymatic saccharification assays of pretreated oat straw}

Untreated oat straw and pretreated samples from lime pretreatment, autohydrolysis processing and combined treatment of autohydrolysis and lime were submitted to enzymatic saccharification under liquid to solid ratio (LSR) of $25 \mathrm{~g} / \mathrm{g}$ and enzyme to solid ratio (ESR) of $25 \mathrm{FPU} / \mathrm{g}$ in order to evaluate the effect of pretreatments on enzymatic susceptibility of cellulose. Celluclast 1.5 and
Novozyme 188 were added to hydrolysis of polysaccharides. Cellulase and $\beta$-glucosidase activities (70 FPU $/ \mathrm{mL}$ and $625 \mathrm{UI} / \mathrm{mL}$ ) were measured following the methods described in Ghose (1987) and Paquot and Thonart (1982). Pretreated samples, water and citrate buffer $(0.05 \mathrm{~N})$ were mixed and placed in an orbital shaker at $48.5^{\circ} \mathrm{C}$ and $150 \mathrm{rpm}$. Samples were withdrawn at desired times and analyzed for glucose and xylose concentration by HPLC.

\subsection{Yeast strains and inoculum preparation}

The strains used in this work were S. cerevisiae PE2 (Pereira et al., 2010, 2011) (isolated from Brazilian bioethanol production plant) and metabolic engineered S. cerevisiae PE2 with xylose pathway (as it was described in Romaní et al., 2015). The stock cultures were maintained on YPD or YPX (1\% $(\mathrm{w} / \mathrm{v})$ of yeast extract, $2 \%$ of bacto-pectone $(\mathrm{w} / \mathrm{v})$ and $2 \%(\mathrm{w} / \mathrm{v})$ of glucose or xylose) agar at $4{ }^{\circ} \mathrm{C}$. For the inoculation, yeast strains were grown in Erlenmeyer flasks containing $50 \mathrm{~g} / \mathrm{L}$ of glucose or xylose, $20 \mathrm{~g} / \mathrm{L}$ of peptone and $10 \mathrm{~g} / \mathrm{L}$ of yeast extract for $15-24 \mathrm{~h}$ at $30^{\circ} \mathrm{C}$. Cell suspension was collected by centrifugation ( $10 \mathrm{~min}$ at $7500 \mathrm{~g}$ and $4{ }^{\circ} \mathrm{C}$ ) and resuspended in $0.9 \% \mathrm{NaCl}$ to a concentration of $200 \mathrm{~g}$ fresh yeast/ L. Experiments of simultaneous saccharification and fermentation were inoculated with $8 \mathrm{~g} / \mathrm{L}$ of this suspension (corresponding to $1.8 \mathrm{~g}$ of dry cell/L).

\subsection{Simultaneous saccharification and fermentation (SSF) for ethanol production}

Pretreated samples were employed to produce ethanol by simultaneous saccharification and fermentation. Assays were carried out at $35^{\circ} \mathrm{C}, \mathrm{pH}=5$ and $150 \mathrm{rpm}$ in an orbital incubator. Pretreated substrates were mixed with water at liquid to solid ratio of 7 and $20 \mathrm{~g} / \mathrm{g}$ using an enzyme loading of 10 and $20 \mathrm{FPU} / \mathrm{g}$. Inoculum and nutritional supplementation of peptone and yeast extract were also added with a final concentration of 20 and $10 \mathrm{~g} / \mathrm{L}$ of peptone and yeast extract. Samples were withdrawn at desired times and analyzed by HPLC for sugars (glucose, xylose) and ethanol concentration.

\section{Results and discussion}

\subsection{Raw material composition}

Extractives determination was carried out by two sequential extractions using water and $80 \%$ of ethanol as solvents. Total extractives represented $14.23 \%$ of raw material in which $12.45 \%$ was soluble in water and $1.8 \%$ was soluble in ethanol. Aqueous extraction was directly analyzed by HPLC for sugar determination. 
Glucose and xylose were detected and represented a 2.15 and $3.19 \mathrm{~g}$ of glucose and xylose $/ 100 \mathrm{~g}$ of raw material, respectively. Oat straw without extractives was analyzed for structural components (cellulose or glucan, hemicellulose and Klason lignin). Chemical composition of oat straw, expressed in $\mathrm{g}$ component/100 g oven-dry raw material \pm standard deviation, based in three replicates, was as follow: $37.10 \pm 1.96$ of glucan, $19.49 \pm 0.48$ of xylan, $2.38 \pm 0.37$ of arabinan, $1.44 \pm 0.37$ of acetyl groups, $21.29 \pm 2.01$ of Klason lignin and $1.86 \pm 0.08$ of ashes. Glucan content was the major component of oat straw followed by hemicellulose (composed by xylan, arabinan and acetyl groups) and Klason lignin. Xylan was the majority component of hemicellulose which represented an $83.6 \%$ of identified hemicellulose content. This composition is typical of agro-industrial residues (Vargas et al., 2015; García-Cubero et al., 2010).

\subsection{Evaluation of lime pretreatment on fractionation and enzymatic susceptibility}

\subsubsection{Chemical composition of lime pretreated oat straw}

The first objective of this work was to study the effect of lime pretreatment on fractionation of oat straw. The range of operational conditions (temperature, time and $\mathrm{Ca}(\mathrm{OH})_{2}$ loading) evaluated were chosen in basis of literature (Tao et al., 2011; Jutakanoke et al., 2012; Zhao et al., 2013; Rabelo et al., 2013) and listed in Table 1 . Firstly, a temperature of $121^{\circ} \mathrm{C}$ was assayed at different lime loadings (0.1-0.6 $\mathrm{g} \mathrm{Ca}(\mathrm{OH})_{2} / \mathrm{g}$ of oat straw) with a fixed time of $60 \mathrm{~min}$ (run 1-4). After that, the range of time and temperature was extended ( 90 and $134^{\circ} \mathrm{C}$ and $30-240 \mathrm{~min}$ ) corresponding to experiments 6-12 (Table 1 ) in order to evaluate their effect. Chemical composition (glucan, xylan and Klason lignin) and solid yield after lime pretreatment were also collected in Table 1. Other components of oat straw (arabinan and acetyl groups) were detected in low concentration ( $<1 \mathrm{~g}$ of component/100 $\mathrm{g}$ of lime pretreated oat straw) and were not included in Table 1.

Solid yield varied in the range of $54.8-76.2 \mathrm{~g}$ of pretreated lime/100 $\mathrm{g}$ of oat straw (corresponding to run 8 and 11, respectively). The highest SY was obtained at low temperature $\left(90^{\circ} \mathrm{C}\right)$ and lime loading $(0.1 \mathrm{~g} / \mathrm{g})$ and the lowest SY was obtained for the highest temperature $\left(134^{\circ} \mathrm{C}\right)$ which shows a relevant importance of temperature on solubilization of oat straw biomass. From these results, an average solubilization of $36 \%$ was calculated. As can be observed in Table 1 , SY was $<60 \%$ at temperature of $134{ }^{\circ} \mathrm{C}$ and $60 \mathrm{~min}$. Glucan content of lime pretreated oat straw varied in the range of $41.4-52.6 \mathrm{~g}$ of glucan/100 g of pretreated oat straw. The percentage of glucan with respect to raw material increased up to $28 \%$ which indicated a higher retention of glucan than xylan and lignin in solid phase after lime pretreatment. As general trend, a temperature rise in lime pretreatment increased the percentage of glucan content in pretreated oat straw. This fact could be due to solubilization of lignin and xylan which allows obtaining a spent oat straw enriched mainly in glucan. Similar results were observed in published papers using pretreated lime sugarcane bagasse (Rabelo et al., 2013; Grimaldi et al., 2015). Regarding to hemicellulose content in lime pretreated samples, xylan content ranged from 16.4 to $20.6 \%$ (average value of $19.1 \%$ ). On the other hand, Klason lignin content was in the range of $16.3-19.8 \%$ (17.7\% of average content). After lime pretreatment, xylan and Klason lignin content ( $\mathrm{g}$ of component/100 $\mathrm{g}$ of raw material) was removed in similar amount with respect to initial xylan and Klason lignin in raw material. Interestingly using $0.4 \mathrm{~g}$ of lime/g and $134^{\circ} \mathrm{C}$ (run 6 and 8), the highest amount of glucan (in $\mathrm{g}$ ) per $\mathrm{g}$ of Klason lignin (expressed in $\mathrm{g}$ of component $/ 100 \mathrm{~g}$ of raw material) was achieved, showing the effect of lime pretreatment on the recovery of glucan related with the amount of Klason lignin that remained in pretreated biomass. On the other hand, the amount of glucan/Klason lignin, using
$0.6 \mathrm{~g}$ of lime loading/g of oat straw (run 3), was lower than the one obtained with lime loading of $0.4 \mathrm{~g} / \mathrm{g}$ (see Table 1). This showed that it was not necessary an elevated lime loading.

Fig. 1 showed time and lime loading influence at $121^{\circ} \mathrm{C}, 134^{\circ} \mathrm{C}$ and $90^{\circ} \mathrm{C}$ (Fig. 1a-c) on the recovery of glucan, xylan and Klason Lignin $\left(R_{G n} R_{X n}\right.$ and $\left.R_{K L}\right)$ after pretreatment. Under the operational conditions evaluated in this study, 72.7-96.04\% of glucan, 60.0$90.0 \%$ of xylan and 43.9-61.2 $\mathrm{g}$ of Klason lignin were recovered. As can be observed in Fig. 1a, an increase of lime loading ( $0.6 \mathrm{~g} /$ g) produced higher glucan loss $(>20 \%)$ than other lime concentrations. These results showed that the pretreatment was more selective for the glucan recovery in the solid phase and for lignin removal. Nevertheless, a significant percentage of xylan was solubilized as consequence of the process. The highest recovery of glucan $(96 \%)$ was obtained at $134{ }^{\circ} \mathrm{C}, 30 \mathrm{~min}$ and lime loading of $0.1 \mathrm{~g} /$ $\mathrm{g}$ (run 5) with a percentage of delignification of $41.5 \%$ and xylan solubilization of $20 \%$. These results (high glucan recovery using low lime loading) are interesting for the process economy. Lime loading $(0.1$ or $0.4 \mathrm{~g} / \mathrm{g})$ at $134^{\circ} \mathrm{C}$ and 30 or $60 \mathrm{~min}$ had no significant difference on glucan and xylan recovery, showing a higher influence in the delignification percentage (48.5\%) for $0.4 \mathrm{~g} / \mathrm{g}$ (Fig. 1b). Similar glucan recoveries were obtained (approximately $80 \%$ ) with a lime loading of $0.4 \mathrm{~g} / \mathrm{g}$ for $60 \mathrm{~min}$ and $134^{\circ} \mathrm{C}$ or $121^{\circ} \mathrm{C}$. Nevertheless, delignification percentage was higher $(56 \%)$ at $134{ }^{\circ} \mathrm{C}$ than $121{ }^{\circ} \mathrm{C}(49 \%)$. Considering these results, the pretreatment temperature was decreased to $90{ }^{\circ} \mathrm{C}$ increasing the time (240 min) using the same lime loading $(0.1$ and $0.4 \mathrm{~g} / \mathrm{g})$, results were shown in Fig. 1c. Under these pretreatment conditions, xylan recovery (average of $80 \%$ ) was higher than the one obtained at 121 and $134^{\circ} \mathrm{C}$. The temperature of lime pretreatment clearly had an effect on xylan solubilization since glucan and xylan recovery was higher at the lowest temperature of lime pretreatment $\left(90^{\circ} \mathrm{C}\right)$ than Klason lignin in comparison with results obtained at $121^{\circ} \mathrm{C}$ and $134^{\circ} \mathrm{C}$. Regarding the percentage of delignification, $50 \%$ was achieved for experiments carried out for $240 \mathrm{~min}$, independently of lime loading. As general trend, an increase of time, temperature and lime loading caused a pronounced glucan loss and a higher xylan solubilization and percentage of delignification.

\subsubsection{Enzymatic susceptibility of lime pretreated oat straw}

In order to select the condition of pretreatment from a global perspective of the process, it is necessary to study the effect of the pretreatment on the disruption of three-dimensional structure of oat straw and subsequent enzymatic saccharification improvement. The second goal of this work was to evaluate the enzymatic susceptibility of pretreated oat straw. Thus, samples obtained from lime pretreatment (listed in Table 1) were employed as substrate for enzymatic saccharification assays. Results obtained from enzymatic saccharification (glucose and xylose) were fitted to the empirical equation described by Holtzapple et al. (1984) in order to determine the kinetic parameters of enzymatic saccharification (listed in Table 2). This kinetic modeling was previously used for enzymatic hydrolysis of several pretreated lignocellulosic biomass (wheat straw, Eucalyptus globulus, barley straw) showing a good adjustment of calculated to experimental data (Nidetzky et al., 1993; Romaní et al., 2010; Vargas et al., 2015).

$$
\begin{aligned}
& G_{t}=G_{\max } \cdot \frac{t}{t+t_{1 / 2}} \\
& X_{t}=X_{\max } \cdot \frac{t}{t+t_{1 / 2}}
\end{aligned}
$$

where, $\mathrm{G}_{\mathrm{t}}$ or $\mathrm{X}_{\mathrm{t}}(\mathrm{g} / \mathrm{L})$ are glucose or xylose concentration achieved at time $t, \mathrm{G}_{\max }$ or $\mathrm{X}_{\max }(\mathrm{g} / \mathrm{L})$ are glucose or xylose concentration predicted for an infinite reaction time, $t(h)$ is the time and $t_{1 / 2}(h)$ is 
(a) Lime temperature $121^{\circ} \mathrm{C}$ and $60 \mathrm{~min}$

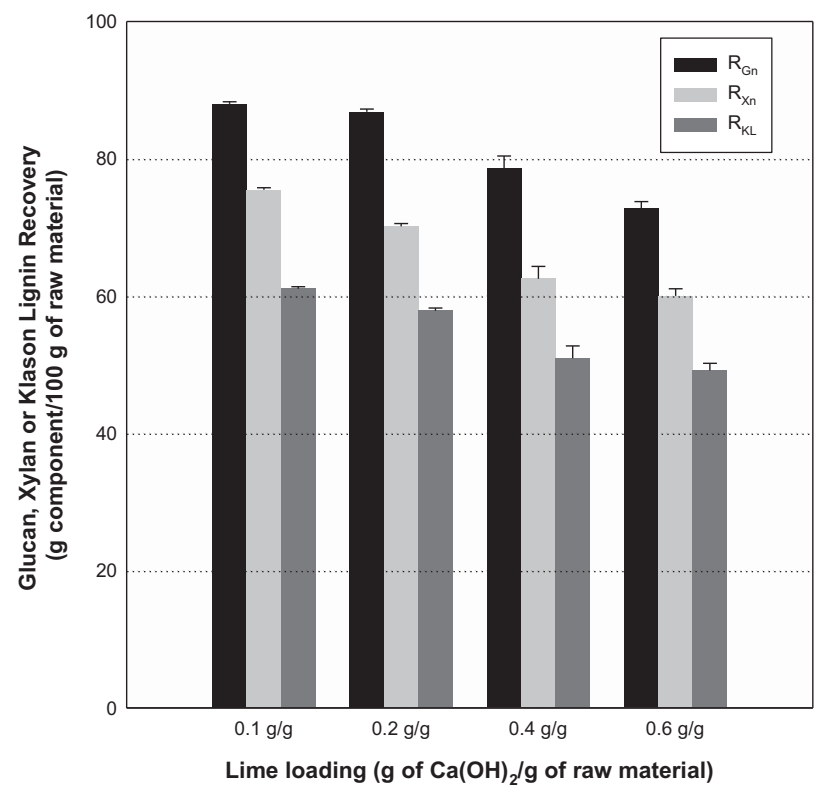

(b) Lime temperature $134^{\circ} \mathrm{C}$

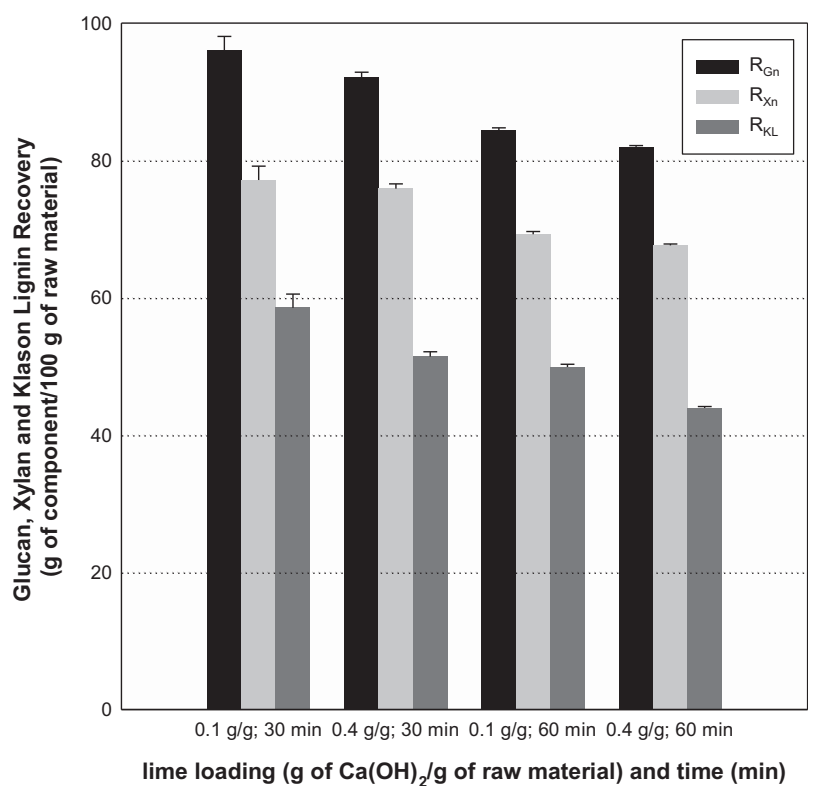

(c) Lime temperature $90^{\circ} \mathrm{C}$

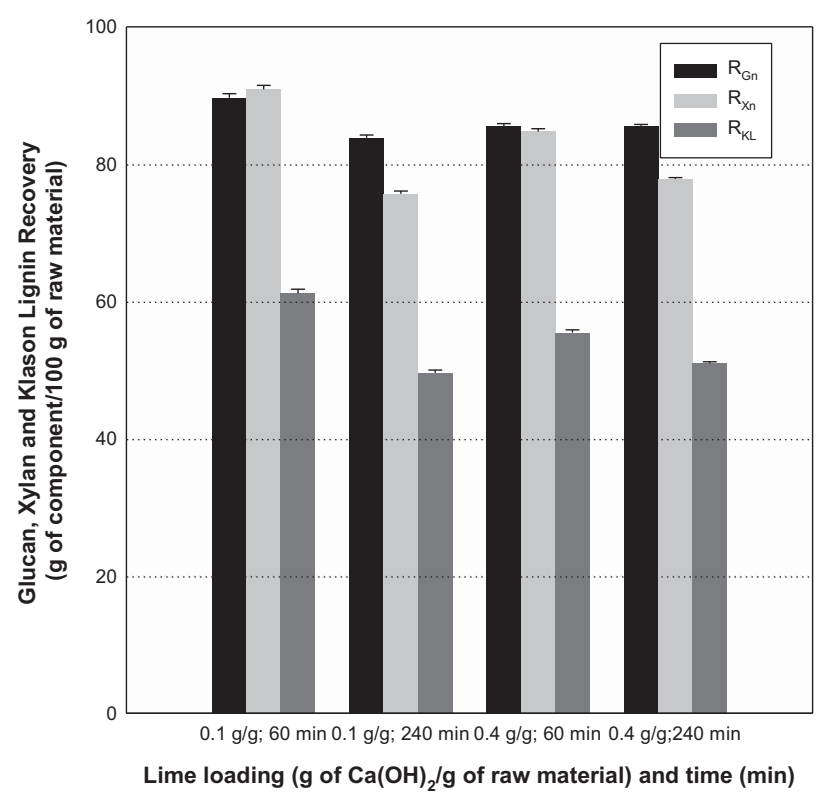

Fig. 1. Recovery of glucan $\left(R_{G n}\right)$, xylan $\left(R_{X n}\right)$ and delignification (D) for experiments corresponding to: a) run 1-4; b) run 5-8 and c) run $9-12$ listed in Table 1 .

the time needed to achieve $50 \%$ of $\mathrm{G}_{\max }$ or $\mathrm{X}_{\max }$. Glucan-to-glucose conversion $\left(\mathrm{CGnG}_{\max }, \%\right)$ or xylan-to-xylose conversion ( $\left.\mathrm{CXnX}_{\max }, \%\right)$ were also calculated and included in Table 2. Conversion of glucan and xylan was defined as the ratio between $G_{\max }$ or $X_{\max }$ released in enzymatic saccharification of lime pretreated and potential glucose or xylose (corresponding to the total conversion of glucan or xylan into glucose or xylose, respectively).

Fig. 2 showed the results obtained from enzymatic hydrolysis of lime pretreated oat straw. As can be observed, experimental data displayed a good adjustment to empirical model with a $\mathrm{R}^{2}$ ranging from 0.968 to 0.997 . The concentration of glucose at $72 \mathrm{~h}$ of hydrolysis achieved 10.9-18.3 g/L being almost constant from $24 \mathrm{~h}$ for most experiments. It is noteworthy to comment that xylose was also released, achieving a concentration of $4.2-8.7 \mathrm{~g} / \mathrm{L}$. In order to determine the effect of lime pretreatment on enzymatic saccharification enhancement, an additional assay of untreated oat straw saccharification was also carried out in which a glucan to glucose conversion of $28 \%$ was obtained. Table 2 recollected results (sugar concentration and conversion) obtained by equation 4 and 5 . Interestingly, values of $t_{1 / 2}<5 \mathrm{~h}$ for sugars production were obtained, showing a high saccharification rate for all of the assays carried out. Nevertheless, glucan conversion varied in the range of 49$95 \%$. Therefore, the conditions of lime treatment did not have the same influence on enzymatic susceptibility and in the saccharification rate. Lime pretreatment can lead to changes on surface area, porosity and crystallinity (Kim et al., 2016) due to hemicellulose and lignin removal. These physical changes produced by the lime pretreatment (re-localization of lignin and low lignin 
Table 2

Main results obtained from saccharification of glucan and xylan.

\begin{tabular}{|c|c|c|c|c|c|c|}
\hline \multirow[t]{2}{*}{ Run } & \multicolumn{3}{|c|}{ Glucan saccharification } & \multicolumn{3}{|c|}{ Xylan saccharification } \\
\hline & $\mathrm{G}_{\mathrm{MAX}}(\mathrm{g} / \mathrm{L})$ & $\mathrm{t}_{1 / 2}(\mathrm{~h})$ & $\mathrm{CGnG}_{\mathrm{MAX}}(\%)$ & $\mathrm{X}_{\text {MAX }}(\mathrm{g} / \mathrm{L})$ & $\mathrm{t}_{1 / 2}(\mathrm{~h})$ & $\mathrm{CXnX}_{\mathrm{MAX}}(\%)$ \\
\hline 1 & 16.2 & 2.9 & 86.4 & 6.3 & 3.7 & 87 \\
\hline 2 & 12.3 & 1.8 & 62.8 & 5.3 & 3.9 & 63 \\
\hline 3 & 15.7 & 2.2 & 78.7 & 7.2 & 2.9 & 90 \\
\hline 4 & 16.8 & 5.0 & 86.8 & 7.9 & 5.2 & 100 \\
\hline 5 & 15.8 & 2.0 & 74.5 & 8.7 & 4.0 & 100 \\
\hline 6 & 16.0 & 2.1 & 71.3 & 7.9 & 2.7 & 91 \\
\hline 7 & 11.4 & 1.8 & 51.4 & 6.0 & 2.4 & 69 \\
\hline 8 & 11.1 & 2.4 & 49.0 & 5.9 & 2.6 & 65 \\
\hline 9 & 18.7 & 5.0 & 95.0 & 9.2 & 3.4 & 100 \\
\hline 10 & 15.1 & 5.0 & 81.9 & 8.7 & 4.2 & 98 \\
\hline 11 & 12.4 & 4.4 & 69.1 & 7.4 & 4.9 & 85 \\
\hline 12 & 15.4 & 3.1 & 78.4 & 9.2 & 4.1 & 100 \\
\hline
\end{tabular}
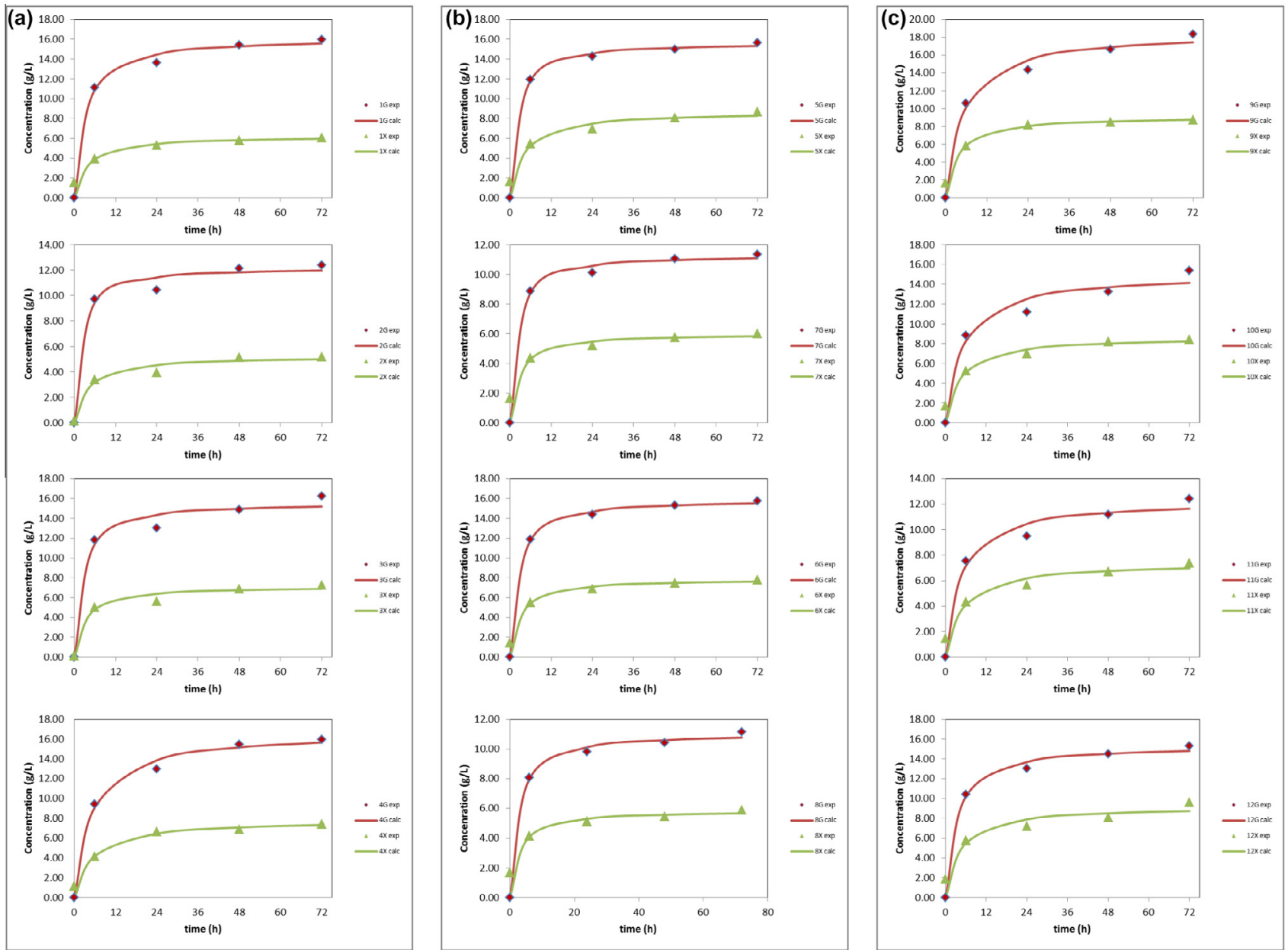

Fig. 2. Enzymatic saccharification of lime pretreated oat straw (operational conditions listed in Table 1) a) run 1-4; b) run 5-8 and c) run 9-12.

concentration) can be related with the enhanced enzymatic saccharification. On the other hand, xylan to xylose conversion was almost complete reaching the $100 \%$. Compared to results obtained from untreated sample, 3.4 fold higher glucan to glucose conversion was obtained with lime pretreatment (run 9). This result can be positively compared with reported data in which 2 times more sugar yield was obtained using lime-pretreated coastal bermudagrass (CBG) than untreated CBG (Wang and Cheng, 2011). An improvement of enzymatic saccharification using lime as pretreatment was also reported using other raw materials such as switchgrass pretreated with oxidative lime (Falls et al., 2011), sugarcane bagasse processed at $90^{\circ} \mathrm{C}, 90 \mathrm{~h}$ and $0.47 \mathrm{~g}$ of Ca $(\mathrm{OH})_{2} / \mathrm{g}$ of bagasse (Rabelo et al., 2013) and wheat straw pretreated by $\mathrm{NaOH}(0.18 \mathrm{~g} / \mathrm{g})$ and lime $(0.06 \mathrm{~g} / \mathrm{g})$ at $80^{\circ} \mathrm{C}$ for $39 \mathrm{~min}$ (Jasaimut et al., 2013). Conditions of lime pretreatment $\left(134^{\circ} \mathrm{C}\right.$, $30 \mathrm{~min}$ and $0.1 \mathrm{~g}$ of lime/g of raw material) were selected for further ethanol production taking into account that (under these conditions) the highest glucan recovery (96\%) was reached with a glucan conversion of $75 \%$ using short time and low lime loading.

Lime pretreatment allowed a delignification percentage of $47 \%$ (average value \pm 5.39 ), a glucan recovery of $85.4 \%$ in solid phase and a xylan (main component of hemicellulose fraction) 
solubilization of $10-40 \%$. The low xylan recovery can be due the amorphous nature of the xylan being more susceptible to be solubilized in aqueous medium than cellulose. In fact, hemicellulose can only be partially removed when lime alkali delignification treatment is employed as first stage of biomass refining (Kim et al., 2012). To improve hemicellulose fractionation, two-step pretreatment has been proposed (such as dilute acid followed by alkali or organosolv delignification processes) as alternative to only one step of processing (Kim et al., 2012; Gong et al., 2011).

\subsection{Evaluation of sequential pretreatment combination: autohydrolysis and lime pretreatment on fractionation and enzymatic saccharification}

In this study, an alternative process configuration considering two stages (autohydrolysis and lime treatment) was developed with the goal to fully recover the hemicellulosic fraction in a separated stream. Spent solid from autohydrolysis was submitted to a second step of delignification by lime pretreatment. Table 3a showed the chemical composition of oat straw from autohydrolysis process. Glucan and Klason lignin recovery (calculated by Eq. (1)) was higher than $94 \%$ and $70 \%$, respectively. On the other hand, 10.9-35.4\% of initial xylan was recovered in solid phase which indicated a high solubilization of xylan. Liquid phase after autohydrolysis was analyzed for oligosaccharides concentration (Table 3b). A maximal concentration of xylooligosaccharides or XOS (13.15 g of XOS/100 g of raw material) was achieved at $\mathrm{S}_{0}=4.08$. The amount of xylooligosaccharides and xylose quantified in liquid phase corresponded to xylan solubilization of 60.8$68.6 \mathrm{~g}$ of xylooligosacharides and xylose/100 $\mathrm{g}$ of xylan in raw material for $S_{0}: 3.94-4.38$. Interestingly, it was possible to obtain $13.47 \mathrm{~g}$ of hemicellulose-derived compounds (measured as xylooligosaccharides and xylose)/100 g of raw material and glucan to glucose conversion of $93.2 \%$ from autohydrolyzed oat straw spent solid at severity of autohydrolysis $\mathrm{S}_{0}=4.22$ (Table 3 ).

Considering the results obtained in lime pretreatment (Table 1 ), the following intermediate lime conditions $\left(121^{\circ} \mathrm{C}, 60 \mathrm{~min}\right.$ and $0.4 \mathrm{~g} / \mathrm{g}$ of lime loading) were selected. The lime loading was chosen taking into account higher delignification percentages previously obtained at milder temperature $\left(121^{\circ} \mathrm{C}\right)$ in order to avoid the increase of polysaccharides losses. Table 3a also showed the composition of oat straw after two-stage treatment (autohydrolysis and lime). As can be observed, glucan content considerably increased up to $70 \mathrm{~g}$ of glucan/100 $\mathrm{g}$ of pretreated oat straw. On the other hand, Klason lignin content ranged from 21.4 to $23.5 \mathrm{~g}$ of Klason lignin/100 g of pretreated oat straw which represented a percentage of delignification of 41.9 and 56.7\%, respectively. These results were comparable with delignification obtained with only one stage of lime pretreatment in which delignification percentage ranged from 38.8 to $56 \%$. On the other hand, the glucan recovery with respect to initial glucan in raw material varied from 88.53 to $76.14 \%$ which implies an average glucan loss of $17.8 \%$ in the overall process. Enzymatic susceptibility of oat straw pretreated by two sequential stages (Table 2) was also evaluated, achieving $99 \%$ of glucan to glucose conversion. Considering the overall yield of glucose, autohydrolysis experiment at $S_{0}=4.22$ followed by lime pretreatment was chosen for further step of saccharification and fermentation. Similar process strategies, combining lime pretreatment with other treatments, were reported in literature. Corn stover was pretreated with hydrochloric acid $\left(120^{\circ} \mathrm{C}\right.$ for $40 \mathrm{~min}$ ) followed by lime $\left(0.1 \mathrm{~g} / \mathrm{g}\right.$ at $60^{\circ} \mathrm{C}$ for $\left.12 \mathrm{~h}\right)$ treatment resulting in $85.9 \%$ of cellulose to glucose conversion using $10 \mathrm{FPU} / \mathrm{g}$ of enzyme (Zu et al., 2014). Other interesting strategy was reported by Sierra et al. (2009) that used physical treatment (ball milling) on lime-treated poplar achieving $100 \%$ of glucan conversion.

\subsection{Evaluation of two process configuration on enzymatic susceptibility and ethanol production by simultaneous saccharification and fermentation (SSF)}

The stages of pretreatment proposed in this work were carried out in order to improve the enzymatic susceptibility of glucan present in oat straw. Enzymatic saccharification improvements of 47, 62.5 and $71.2 \%$ respect to enzymatic hydrolysis of untreated oat straw were obtained from lime pretreatment $\left(134^{\circ} \mathrm{C}, 30 \mathrm{~min}\right.$ and $0.1 \mathrm{~g}$ of lime $/ \mathrm{g}$ of oat straw), autohydrolysis $\left(\mathrm{S}_{0}=4.22\right)$, and sequential autohydrolysis and lime pretreatments $\left(\mathrm{S}_{0}=4.22\right.$ and $121{ }^{\circ} \mathrm{C}, 60 \mathrm{~min}$ and $0.4 \mathrm{~g}$ of lime/g of oat straw), respectively. As was expected, the combination of pretreatments allowed higher enzymatic conversion of glucan (99\%). The glucose concentration from combined treatments was superior $(30.4 \mathrm{~g} / \mathrm{L})$ than glucose obtained from lime $(15.7 \mathrm{~g} / \mathrm{L})$ and autohydrolysis $(23.9 \mathrm{~g} / \mathrm{L})$ pretreatments. This fact can be due to higher glucan content in the pretreated oat straw as consequence of selective hemecellulosic solubilization (80.5 $\mathrm{g}$ of xylan in autohydrolyzed oat straw/100 $\mathrm{g}$

Table 3

Chemical composition of pretreated oat straw by autohydrolysis and combined autohydrolysis and lime pretreatment.

\begin{tabular}{|c|c|c|c|c|c|c|c|c|c|c|}
\hline \multicolumn{9}{|c|}{$\begin{array}{l}\text { a) Chemical composition of oat straw after autohydrolysis and combined treatments of autohydrolysis and lime (g component/100 g of } \\
\text { pretreated oat straw) }\end{array}$} & \multicolumn{2}{|c|}{$\begin{array}{l}\text { Enzymatic } \\
\text { saccharification } \\
\text { results }\end{array}$} \\
\hline \multicolumn{5}{|c|}{ Pretreatment conditions } & \multirow[t]{2}{*}{ Solid yield } & \multirow[t]{2}{*}{ Glucan } & \multirow[t]{2}{*}{ Xylan } & \multirow[t]{2}{*}{ Klason lignin } & \multirow[t]{2}{*}{$\mathrm{G}_{72}(\mathrm{~g} / \mathrm{L})$} & \multirow[t]{2}{*}{ GnGC (\%) } \\
\hline \multicolumn{3}{|c|}{ First stage: autohydrolysis ( $\mathrm{S}_{0}$, dimensionless) } & \multicolumn{2}{|l|}{ Second stage: lime } & & & & & & \\
\hline \multicolumn{3}{|l|}{3.94} & \multicolumn{2}{|l|}{-} & 61.78 & 55.77 & 9.57 & 18.58 & 18.58 & 79.21 \\
\hline \multicolumn{3}{|l|}{4.08} & & & 57.48 & 57.13 & 8.77 & 21.80 & 21.80 & 85.86 \\
\hline \multicolumn{3}{|l|}{4.22} & & & 57.00 & 57.72 & 6.67 & 23.91 & 23.91 & 93.19 \\
\hline \multicolumn{3}{|l|}{4.38} & & & 58.46 & 56.84 & 3.12 & 23.39 & 23.39 & 89.46 \\
\hline \multicolumn{3}{|l|}{3.94} & \multicolumn{2}{|c|}{$121^{\circ} \mathrm{C} ; 60 \mathrm{~min} ; 0.4 \mathrm{~g}$ of lime/g of oat straw } & 85.12 & 62.46 & 6.51 & 23.5 & \multirow{4}{*}{30.35} & \multirow{4}{*}{99.24} \\
\hline \multicolumn{3}{|l|}{4.08} & & & 81.23 & 68.84 & 4.99 & 21.44 & & \\
\hline \multicolumn{3}{|l|}{4.22} & & & 73.02 & 68.82 & 3.41 & 22.24 & & \\
\hline \multicolumn{5}{|l|}{4.38} & 69.01 & 70.03 & 1.9 & 22.84 & & \\
\hline \multicolumn{11}{|c|}{ b) Chemical composition of liquid phase from autohydrolysis pretreatment ( $\mathrm{g}$ of component/100 $\mathrm{g}$ of raw material) } \\
\hline $\mathrm{S}_{0}(-)$ & Glucose & Xylose & Arabinose & Acetic acid & \multicolumn{2}{|c|}{ GOS } & \multicolumn{2}{|c|}{ xOS } & ArOs & $\mathrm{AcOH}$ \\
\hline \multirow{4}{*}{$\begin{array}{l}3.94 \\
4.08 \\
4.22 \\
4.38\end{array}$} & 0.49 & 1.12 & 0.79 & 1.45 & \multicolumn{2}{|c|}{4.58} & 11 & & 0.50 & 0.43 \\
\hline & 0.60 & 2.02 & 0.92 & 1.83 & & & 13 & & 0.00 & 0.41 \\
\hline & 0.70 & 2.70 & 0.28 & 2.19 & & & 10 & & 0.11 & 0.28 \\
\hline & 0.86 & 3.07 & 0.27 & 2.33 & & & 5.8 & & 0.00 & 0.28 \\
\hline
\end{tabular}


of oat straw) of autohydrolysis. The enzymatic susceptibility was considerably improved by autohydrolysis process obtaining comparable results with the oat straw processed in two stages. The overall enhancement obtained in the two configurations allowed to progress towards ethanol fermentation in simultaneous process.

Table 4 showed conditions of simultaneous saccharification and fermentation of pretreated oat straw and main results obtained. S. cerevisiae PE-2 strain was used for fermentation of glucose and ethanol production. As can be seen in Table 4, a higher solid loading (LSR $=7 \mathrm{~g} / \mathrm{g}$ ) was evaluated in order to achieve ethanol concentration of $4 \% \mathrm{w} / \mathrm{w}$ (considered the goal for a competitive lignocellulose-to-ethanol process) (Kroppan et al., 2014). In addition two enzyme loadings were assayed (20 and $10 \mathrm{FPU} / \mathrm{g}$ ) in order to study the effect of enzyme addition on pretreated oat straw samples. As can be observed in Table 4, higher ethanol concentrations were obtained from sequential pretreatments (maximal ethanol concentration of $49.9 \mathrm{~g} / \mathrm{L}$ corresponding to SSF-6) due to higher content of glucan in these pretreated samples (SSF-4 to SSF-7) and more disrupted structure of substrate (glucan to ethanol conversion was also higher). Enzyme loading of $10 \mathrm{FPU} / \mathrm{g}$ was satisfactory for two sequential stages of pretreatment achieving ethanol conversion $>70 \%$. Nevertheless for lime pretreatment and $10 \mathrm{FPU} / \mathrm{g}$ of enzyme loading (SSF-2), ethanol conversion considerably decreased (up to EC $=52 \%$ ) showing ESR of $20 \mathrm{FPU} / \mathrm{g}$ was more favorable for saccharification and fermentation. The maximal ethanol concentration obtained from lime pretreatment was $33.87 \mathrm{~g} / \mathrm{L}$.
Considering that xylan remained in the lime pretreated oat straw, metabolic engineered S. cerevisiae PE-2 strain (Romaní et al., 2015) was used for an additional SSF experiment (under conditions of SSF-3) in which an ethanol concentration of $41.36 \mathrm{~g} / \mathrm{L}$ was achieved. The use of metabolic engineered strain allowed to attain competitive concentration of ethanol since hemicellulose-derived sugars (mainly xylose) can be further metabolized increasing by $22 \%$ the ethanol concentration. Ethanol yield of $68 \%$ (considering glucose and xylose) was reported by Wang and Cheng (2011) using enzymatic hydrolysate from lime pretreated coastal bermudagrass $\left(100{ }^{\circ} \mathrm{C}\right.$ for $15 \mathrm{~min}$ and $0.1 \mathrm{~g} / \mathrm{g}$ ).

\subsection{Comparison of two process configurations: overall mass balance}

In order to compare the results discussed above, Figs. 3 and 4 showed mass balances for main components constituting oat straw biomass following the two configurations proposed. Comparing the two schemes, from lime pretreatment option (Fig. 3) per $100 \mathrm{~kg}$ of oat straw: $6.45 \mathrm{~kg}$ of oligosaccharides (suitable for food industry as functional food), $8.83 \mathrm{~kg}$ of solubilized lignin (which has potential value-added applications) and $22.32 \mathrm{~kg}$ of ethanol were obtained in two separated streams. On the other hand, from autohydrolysis followed by lime pretreatment (Fig. 4) per $100 \mathrm{~kg}$ of oat straw was possible to attain: $15.11 \mathrm{~kg}$ of oligosaccharides, $7.54 \mathrm{~kg}$ of solubilized lignin and $15.91 \mathrm{~kg}$ of ethanol in three separated streams. Regard to operational conditions, autohydrolysis

Table 4

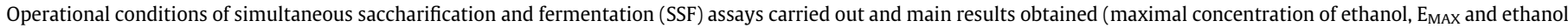
conversion, EC).

\begin{tabular}{|c|c|c|c|c|c|}
\hline \multirow[t]{2}{*}{ Run } & \multirow[t]{2}{*}{ Pretreatment } & \multicolumn{2}{|c|}{ SSF operational condition } & \multicolumn{2}{|c|}{ Main results } \\
\hline & & $\operatorname{LSR}(\mathrm{g} / \mathrm{g})$ & ESR (FPU/g) & $\mathrm{E}_{\mathrm{MAX}}(\mathrm{g} / \mathrm{L})$ & $\mathrm{EC}(\%)$ \\
\hline SSF-1 & Lime pretreatment & 20 & 20 & 9.04 & 64.23 \\
\hline SSF-2 & $\left(134^{\circ} \mathrm{C}, 30 \mathrm{~min}, 0.1 \mathrm{~g} \mathrm{Ca}(\mathrm{OH})_{2} / \mathrm{g}\right)$ & 20 & 10 & 7.32 & 52.02 \\
\hline SSF-3 & & 7 & 20 & 33.87 & 84.22 \\
\hline SSF-4 & Autohydrolysis at $\mathrm{S}_{0}=4.22$ & 20 & 20 & 13.62 & 74.24 \\
\hline SSF-5 & Lime pretreatment $\left(121^{\circ} \mathrm{C}, 60 \mathrm{~min}, 0.4 \mathrm{~g}\right.$ of $\left.\mathrm{Ca}(\mathrm{OH})_{2} / \mathrm{g}\right)$ & 20 & 10 & 14.98 & 81.64 \\
\hline SSF-6 & & 7 & 20 & 49.90 & 95.18 \\
\hline SSF-7 & & 7 & 10 & 46.73 & 89.14 \\
\hline
\end{tabular}

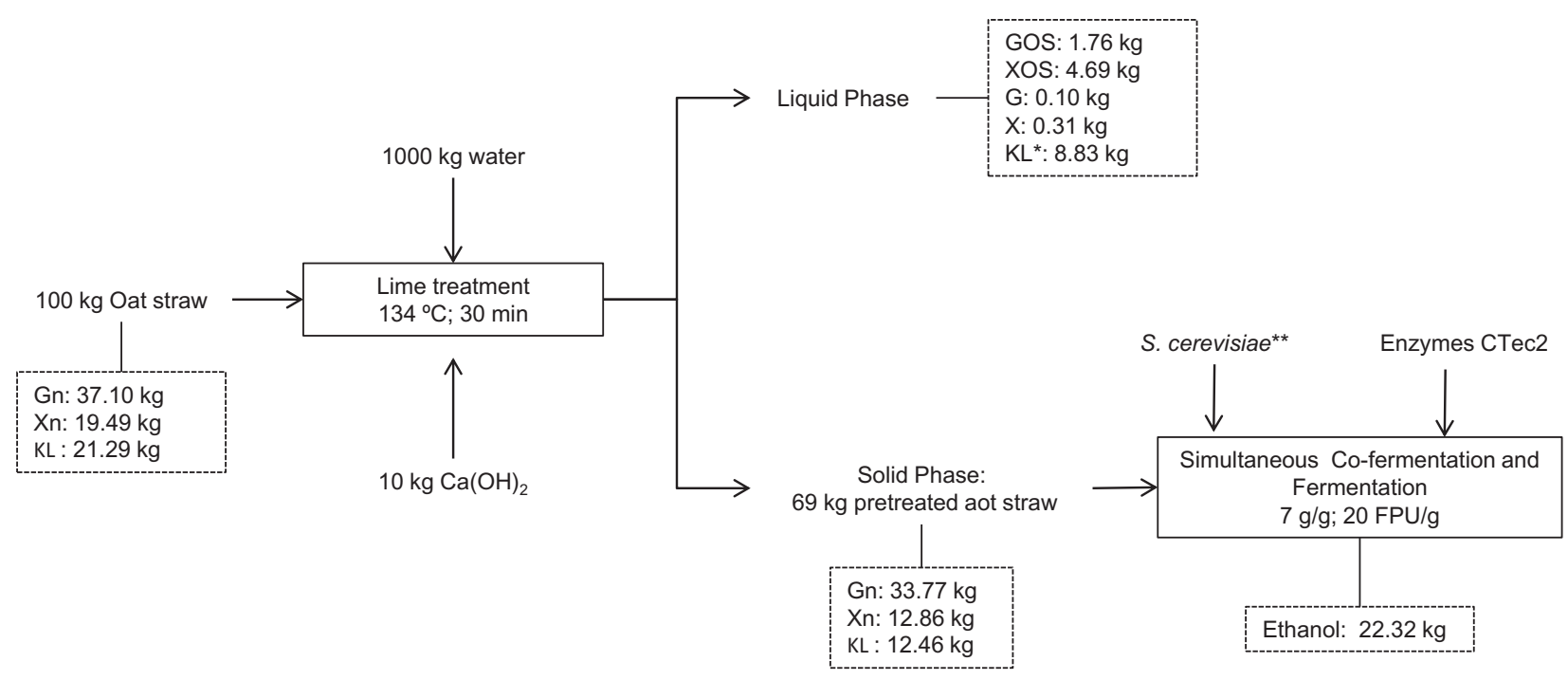

*solubilized Klason lignin (KL) was quantified by difference

${ }^{* *}$ metabolic engineered S. cerevisiae PE2 strain for xylose consumption (Romaní et al., 2015) 


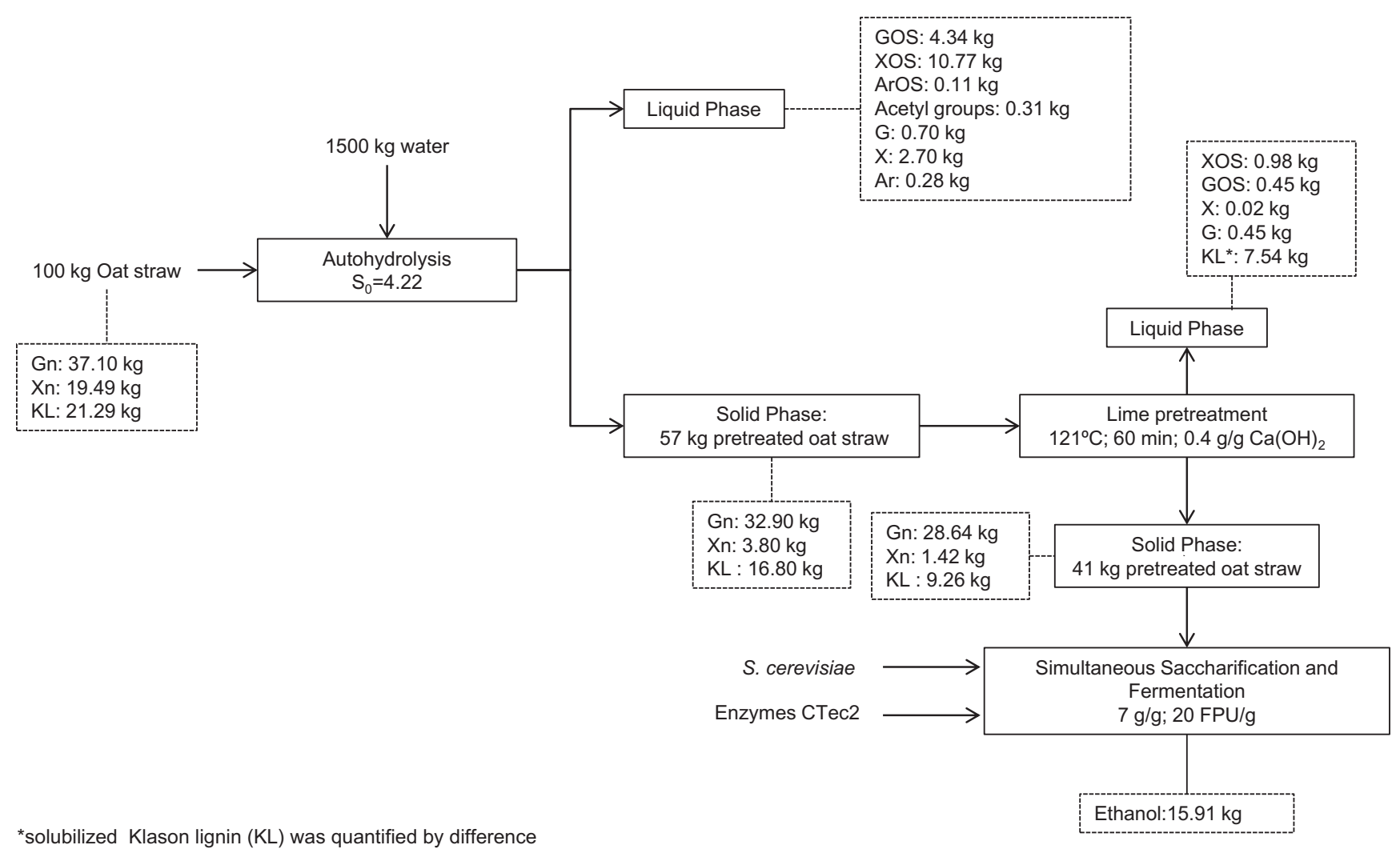

Fig. 4. Overall mass balance of autohydrolysis at $S_{0}=4.22$ followed by lime pretreatment $\left(121^{\circ} \mathrm{C}, 60 \mathrm{~min}\right.$ and $\left.0.4 \mathrm{~g} / \mathrm{g}\right)$.

required the elevated temperatures $\left(>200{ }^{\circ} \mathrm{C}\right)$ to achieve a suitable solubilization of xylan. On the other hand, lime treatment used very short time of pretreatment and lower temperature and pressure than sequential pretreatments. The results shown in this work revealed the importance of selection of pretreatment to reach a satisfactory grade of fractionation that allows manufacturing of value-added products.

\section{Conclusions}

Both pretreatment configurations lead to effective fractionation of oat straw and could be implemented as first stage in a biorefinery. Combined pretreatment with autohydrolysis allowed a higher hemicellulose recovery into oligosaccharides than lime pretreatment. On the other hand, xylan in lime pretreated oat straw was successfully converted to ethanol allowing a higher ethanol yield per $\mathrm{kg}$ of oat straw by lime processing. An ethanol concentration superior to $4 \%(\mathrm{w} / \mathrm{w})$ defined as the goal for competitive lignocellulose-to-ethanol process was achieved in both cases. Lime pretreatment combined or not with autohydrolysis was effective for oat straw valorization within a biorefinery concept.

\section{Acknowledgements}

The authors thank the financial support from the Strategic Project of UID/BIO/04469/2013 CEB Unit (Funding agency for Science and Technology, FCT, Portugal) and for the Project CTQ201230855 of the Spanish "Ministry of Science and Innovation", partially funded by the FEDER program of the European Union. A Romaní thanks her post-doctoral grant funded by Xunta of Galicia (Plan I2C, 2014).

\section{References}

Akhtar, N., Gupta, K., Goyal, D., Goyal, A., 2016. Recent advances in pretreatment technologies for efficient hydrolysis of lignocellulosic biomass. Environ. Prog. Sustainable Energy 35 (2), 489-511.

Berger, K., Falck, P., Linnige, C., Nilsson, U., Axling, U., Grey, C., Stalbrand, H., Karlsson, E.N., Nyman, M., Holm, C., Adlercreutz, P., 2014. Cereal byproducts have prebiotic potential in mice fed a high-fat diet. J. Agric. Food Chem. 62, 8169-8178.

Chen, X., Önal, H., 2016. Renewable energy policies and competition for biomass: implications for land use, food process, and processing industry. Energy Policy 92, 270-278.

Cunha, J.T., Aguiar, T.Q., Romaní, A., Oliveira, C., Domingues, L., 2015. Contribution of PRS3, RPB4 and ZWF1 to the resistance of industrial Saccharomyces cerevisiae CCUG53310 and PE-2 strains to lignocellulosic hydrolysate-derived inhibitors. Bioresour. Technol. 191, 7-16.

Dereire, D.Y., Tobro, S., Momeni, M.H., Hansson, H., Blomqvist, J., Passoth, V., Schnürer, M., Stahlberg, 2010. Improved bio-energy yields via sequential ethanol fermentation and biogas digestion of steam exploded oat straw. Bioresour. Technol. 102, 4449-4455.

Falls, M., Sierra-Ramírez, R., Holtzapple, M.T., 2011. Oxidative lime pretreatment of Dacotah swithchgrass. Appl. Biochem. Biotechnol. 165, 243-259.

García-Cubero, M.T., Coca, M., Bolado, S., González-Benito, G., 2010. Chemical oxidation with ozone as pre-treatment of lignocellulosic materials for bioethanol production. Chem. Eng. Trans. 21, 1273-1278.

Garrote, G., Domínguez, H., Parajó, J.C., 1999. Hydrothermal processing of lignocellulosic materials. Holz als Roh-und Werkstoff 57 (3), 191-202.

Ghose, T.S., 1987. Measurement of cellulase activities. Pure Appl. Chem. 59, 257268.

Gómez-Tovar, F., Celis, L.B., Razo-Flores, E., Alatriste-Mondragón, F., 2012. Chemical and enzymatic sequential pretreatment of oat straw for methane production. Bioresour. Technol. 116, 372-378.

Gong, D., Holtman, K.M., Franqui-Espiet, D., Orts, W.J., Zhao, R., 2011. Development of an integrated pretreatment fractionation process for fermentable sugars and lignin: application to almond (Prunus dulcis) shell. Biomass Bioenergy 35, 44354441.

Grimaldi, M.P., Marques, M.P., Laluce, C., Cilli, E.M., Sponchiado, S.R.P., 2015. Evaluation of lime and hydrothermal pretreatments for efficient enzymatic hydrolysis of raw sugarcane bagasse. Biotechnol. Biofuels 8 (1), 205.

Holtzapple, M.T., Caram, H.S., Humphrey, A.E., 1984. A comparison of two empirical models for the enzymatic hydrolysis of pretreated poplar wood. Biotechnol. Bioeng. 26, 936-941. 
Jasaimut, K., Paulová, P., Rychtera, M., Melzoch, K., 2013. Optimization of alkali pretreatment of wheat straw to be used as substrate for biofuels production. Plant Soil Environ. 59 (12), 537-542.

Jin, M., Sarks, C., Gunawan, C., Bice, B.D., Simonett, S.P., Narasimhan, R.A., Willis, L.B. Dale, B.E., Balan, V., Sato, T., 2013. Phenotypic selection of a wild Saccharomyces cerevisiae strain for simultaneous sacchacarification and co-fermentation of AFEX $^{\mathrm{TM}}$ pretreated corn stover. Biotechnol. Biofuels 6, 108.

Jutakanoke, R., Leepipatpiboon, N., Tolieng, V., Kitpreechavanich, V., Srinarokutara, T., Akaracharanya, A., 2012. Sugarcane leaves: pretreatment and ethanol fermentation by Saccharomyces cerevisiae. Biomass Bionergy 39, 283-289.

Kim, S., Dale, B.E., 2004. Global potential bioethanol production from wasted crops and crop residue. Biomass Bioenergy 26, 361-375.

Kim, S., Park, J.M., Seo, J.W., Kim, C.H., 2012. Sequential acid-/alkali-pretreatment of empty palm fruit bunch fiber. Bioresour. Technol. 109, 229-233.

Kim, J.S., Lee, Y.Y., Kim, T.H., 2016. A review on alkaline pretreatment technology for bioconversion of lignocellulosic biomass. Bioresour. Technol. 199, 42-48.

Kroppan, R., Tomás-Pejó, E., Xiros, C., Olsson, L., 2014. Lignocellulosic ethanol production at high-gravity: challenges and perspectives. Trends Biotechnol. 32, $46-53$.

Lavoie, J.M., Capek-Menard, E., Gauvin, H., Chornet, E., 2010. Production of pulp from Salix viminalis energy crops using the FIRSST process. Bioresour. Technol. $101,4940-4946$

Mosier, N., Wyman, C., Dale, B., Elander, R., Lee, Y.Y., Holtzapple, M., Ladisch, M., 2005. Features of promising technologies for pretreatment of lignocellulosic biomass. Bioresour. Technol. 96 (6), 673-686.

Nidetzky, B., Steiner, W., Hayn, M., Esterbauer, H., 1993. Enzymatic hydrolysis of wheat straw after steam pretreatment: experimental data and kinetic modelling. Bioresour. Technol. 44 (1), 25-32.

Paquot, P.M., Thonart, P., 1982. Hydrolyze enzimatique de la cellulose regeneree. Holzforschung 36 (4), 177-181.

Pereira, F.B., Guimarães, P.M.R., Teixeira, J.A., Domingues, L., 2010. Selection of Saccharomyces cerevisiae strains for efficient very high gravity bio-ethanol fermentation processes. Biotechnol. Lett. 32 (11), 1655-1661.

Pereira, F.B., Guimarães, P.M.R., Teixeira, J.A., Domingues, L., 2011. Robust industrial Saccharomyces cerevisiae strains for very high gravity bio-ethanol fermentations. J. Biosci. Bioeng. 112 (2), 130-136.

Pereira, F.B., Romaní, A., Ruiz, H.A., Teixeira, J.A., Domingues, L., 2014. Industrial robust yeast isolates with great potential for fermentation of lignocellulosic biomass. Bioresour. Technol. 161, 192-199.

Rabelo, S.C., Filho, R.M., Costa, A.C., 2013. Lime pretreatment and fermentation of enzymatically hydrolyzed sugar bagasse. Appl. Biochem. Biotechnol. 169, $1696-$ 1712.

Romaní, A., Garrote, G., Alonso, J.L., Parajó, J.C., 2010. Experimental assessment on the enzymatic hydrolysis of hydrothermally pretreated eucalyptus globulus wood. Ind. Eng. Chem. Res. 49 (10), 4653-4663.

Romaní, A., Garrote, G., Alonso, J.L., Parajó, J.C., 2011. Eucalyptus globulus wood fractionation by autohydrolysis and organosolv delignification. Bioresour. Technol. 102 (10), 5896-5904.
Romaní, A., Pereira, F., Johansson, B., Domingues, L., 2015. Metabolic engineering of Saccharomyces cerevisiae ethanol strains PE-2 and CAT-1 for efficient lignocellulosic fermentation. Bioresour. Technol. 179, 150-158.

Ruiz, H.A., Ruzene, D.S., Silva, D.P., Da Silva, F.F.M., Vicente, A.A., Teixeira, J.A., 2011 Development and characterization of an environmentally friendly process sequence (autohydrolysis and organosolv) for wheat straw delignification. Appl. Biochem. Biotechnol. 164, 629-641.

Sapci, Z., 2013. The effect of microwave pretreatment on biogas production from agricultural straws. Bioresour. Technol. 128, 487-494.

Sierra, R., Granda, C., Holtzapple, M.T., 2009. Short-term lime pretreatmnet of poplar wood. Biotechnol. Prog. 25 (2), 323-332.

Singh, J., Suhag, M., Dhaka, A., 2015. Augmented digestion of lignocellulose by stean explosion, acid and alkaline pretreatment methods: a review. Carbohydr. Polym. 117, 624-631.

Tao, L., Aden, A., Elander, R.T., Pallapolu, V.R., Lee, Y.Y., Garlock, R.J., Balan, V., Dale, B. E., Kim, Y., Mosier, N.S., Ladisch, M.R., Falls, M., Holtzapple, M.T., Sierra, R., Shi, J. Ebrik, M.A., Redmond, T., Yang, B., Wyman, C.E., Hames, B., Thomas, S., Warner R.E., 2011. Process and technoeconomic analysis of leading pretreatment technologies for lignocellulosic ethanol production using switchgrass. Bioresour. Technol. 102, 11105-11114.

Vargas, F., Domínguez, E., Vila, C., Rodríguez, A., Garrote, G., 2015. Agricultural residue valorization using a hydrothermal process for second generation bioethanol and oligosaccharides production. Bioresour. Technol. 191, 263-270.

Wang, Z., Cheng, J.J., 2011. Lime pretreatment of coastal bermudagrass for bioethanol production. Energy Fuels 25, 1830-1836.

Wimalasena, T.T., Greetham, D., Marvin, M.E., Liti, G., Chandelia, Y., Hart, A., Louis, E. J., Phister, T.G., Tucker, G.A., Smart, K.A., 2014. Phenotypic characterisation of Saccharomyces ssp. Yeast for tolerance to stress encountered during fermentation of lignocellulosic residues to produce bioethanol. Microb. Cell Fact. 13 (1), 47.

Wyman, C.E., Balan, V., Dale, B.E., Elander, R.T., Falls, M., Hames, B., Holtzapple, M.T. Ladisch, M.R., Lee, Y.Y., Mosier, N., Pallapolu, V.R., Shi, J., Thomas, S.R., Warner, R. E., 2011. Comparative data on effects of leading pretreatments and enzyme loadings and formulations on sugar yields from different switchgrass sources. Bioresour. Technol. 102, 11052-11062.

Yañez, R., Romaní, A., Garrote, G., Alonso, J.L., Parajó, J.C., 2009. Processing of acacia dealbata in aqueous media: first step of a wood biorefinery. Ind. Eng. Chem. Res. 48 (14), 6618-6626.

Yang, B., Wyman, C.E., 2008. Pretreatment: the key to unlocking low-cost cellulosic ethanol. Biofuels Bioprod. Bioref. 2, 26-40.

Zhao, R., Yun, M.-S., Shiroma, R., Ike, M., Guan, D., Tokuyasu, K., 2013. Integration of a phenolic-acid recovery step in the CaCCO process for efficient fermentablesugar recovery from rice straw. Bioresour. Technol. 148, 422-427.

Zu, S., Li, W.-Z., Zhang, M., Li, Z., Wang, Z., Jameel, H., Chang, H.-M., 2014 Pretreatment of corn stover for sugar production using dilute hydrochloric acid followed by lime. Bioresour. Technol. 152, 364-370. 